\title{
The leukocyte telomere length, single nucleotide polymorphisms near TERC gene and risk of COPD
}

\author{
Tanya Tacheva ${ }^{\text {Corresp., }}{ }^{1}$, Shanbeh Zienolddiny ${ }^{2}$, Dimo Dimov $^{1}$, Denitsa Vlaykova $^{1}$, Tatyana Vlaykova $^{1,3}$ \\ 1 Department of Chemistry and Biochemistry, Medical Faculty, Trakia University, Stara Zagora, Bulgaria \\ 2 Section for Toxicology and Biological Work Environment, National Institute of Occupational Health, Oslo, Norway \\ 3 Department of Medical Biochemistry, Medical University - Plovdiv, Plovdiv, Bulgaria \\ Corresponding Author: Tanya Tacheva \\ Email address: tachevat@abv.bg
}

Chronic obstructive pulmonary disease (COPD) is characterized by irreversible airflow obstruction and is associated with chronic local and systemic inflammation and oxidative stress. The enhanced oxidative stress and inflammation have been reported to affect telomere length (TL). Furthermore, a number of SNPs at loci encoding the main components of the telomerase genes, TERT and TERC have been shown to correlate with $T L$. We aimed to explore the leukocyte $T L$ and genotypes for single nucleotide polymorphisms, rs12696304 (C>G) and rs10936599 (C>T) near TERC in COPD cases and matched healthy controls using q-PCR technologies. Successful assessment of TL was performed for 91 patients and 88 controls. The patients had shorter TL

(17919.36 $\pm 1203.01 \mathrm{bp}$ ) compared to controls (21 271.48 $\pm 1891.36 \mathrm{bp}$ ) although not significant $(p=0.137)$. The TL did not associate with the gender, age, spirometric indexes, smoking habits but tended to correlate negatively with BMI (Rho $=-0.215, p=0.076)$ in the controls, but not in COPD patients. The genotype frequencies of the SNPs rs12696304 and rs10936599 were compared between patients and controls and the odds ratios (OR) for developing COPD were calculated. The carriers of the common homozygous genotype of the SNPs had higher risk for COPD, compared to carriers of the variants alleles ( $r s 12696304$ CG+GG vs. CC; OR: $0.631,95 \% \mathrm{Cl}$ 0.427-0.931, $\mathrm{p}=0.020$ and for rs10936599 $\mathrm{CT}+\mathrm{TT}$ vs. $\mathrm{CC} O \mathrm{OR}=0.615,95 \% \mathrm{Cl}: 0.424-0.894, \mathrm{p}=0.011$ ). Analysis on the combined effects of the TERC rs12696304 (C>G) and rs10936599 (C>T) genotypes CC/CC genotype combination was associated with higher risk for COPD $(p<0.0001)$ and marginally lower FEV1\% pr. in patients with GOLD II $(p=0.052)$. There was no association between the SNP genotypes and TL. In summary, our results suggest that COPD patients may have shorter $\mathrm{TL}$, and rs12696304 and rs10936599 near TERC may affect the risk of COPD independently of TL. 
5

6

7

8

9

10

11

12

The leukocyte telomere length, single nucleotide polymorphisms near TERC gene and risk of COPD

${ }^{1}$ Tanya Tacheva, ${ }^{2}$ Shanbeh Zienolddiny, ${ }^{1}$ Dimo Dimov, ${ }^{1}$ Denitsa Vlaykova, ${ }^{1,3}$ Tatyana Vlaykova

${ }^{1}$ Dept. Chemistry and Biochemistry, Medical Faculty, Trakia University, Stara Zagora, Bulgaria

${ }^{2}$ Section for Toxicology and Biological Work Environment, National Institute of Occupational Health, Oslo, Norway

${ }^{3}$ Dept. Medical Biochemistry, Medical University - Plovdiv, Bulgaria

*E-mail: tachevat@abv.bg 


\begin{abstract}
Chronic obstructive pulmonary disease (COPD) is characterized by irreversible airflow obstruction and is associated with chronic local and systemic inflammation and oxidative stress. The enhanced oxidative stress and inflammation have been reported to affect telomere length (TL). Furthermore, a number of SNPs at loci encoding the main components of the telomerase genes, TERT and TERC have been shown to correlate with TL. We aimed to explore the leukocyte TL and genotypes for single nucleotide polymorphisms, rs12696304 (C>G) and rs $10936599(\mathrm{C}>\mathrm{T})$ near TERC in COPD cases and matched healthy controls using q-PCR technologies. Successful assessment of TL was performed for 91 patients and 88 controls. The patients had shorter TL (17919.36 $\pm 1203.01 \mathrm{bp})$ compared to controls (21 271.48 $\pm 1891.36 \mathrm{bp}$ ) although not significant ( $\mathrm{p}=0.137)$. The TL did not associate with the gender, age, spirometric indexes, smoking habits but tended to correlate negatively with BMI $(\mathrm{Rho}=-0.215, \mathrm{p}=0.076)$ in the controls, but not in COPD patients. The genotype frequencies of the SNPs rs12696304 and rs 10936599 were compared between patients and controls and the odds ratios (OR) for developing COPD were calculated. The carriers of the common homozygous genotype of the SNPs had higher risk for COPD, compared to carriers of the variants alleles (rs 12696304 CG+GG vs. CC; OR: 0.631, 95\% CI 0.427-0.931, $\mathrm{p}=0.020$ and for rs 10936599 CT+TT vs. CC $\mathrm{OR}=0.615,95 \% \mathrm{CI}: 0.424-0.894, \mathrm{p}=0.011)$. Analysis on the combined effects of the TERC rs $12696304(\mathrm{C}>\mathrm{G})$ and $\mathrm{rs} 10936599(\mathrm{C}>\mathrm{T})$ genotypes CC/CC genotype combination was associated with higher risk for COPD $(\mathrm{p}<0.0001)$ and marginally lower FEV1\% pr. in patients with GOLD II ( $p=0.052)$. There was no association between the SNP genotypes and TL. In summary, our results suggest that COPD patients may have shorter TL, and rs12696304 and rs 10936599 near TERC may affect the risk of COPD independently of TL.
\end{abstract}




\section{Introduction}

COPD is chronic inflammatory disease characterized by increased mucus production, shortness of breath and cough with sputum production. One of the big challenges in diagnosis and management of COPD come from the fact that many patients may not recognize their symptoms as being due to the disease but rather due to aging, smoking etc. The pathological changes occur in the proximal and distal airways, as well as in the parenchyma of the lungs. Chronic inflammation, oxidative stress, ageing of the cells and the remodeling of the airways are thought to play central role in the pathogenesis of the disease (Chung \& Adcock 2008; GOLD 2017; Lange et al. 2016; Pauwels \& Rabe 2004).

Cellular aging, or senescence, results in series of alterations in cell morphology and function, including the loss of proliferative activity (MacNee 2009). Aging of somatic cells results in a depletion of their potential of division due to shortening of telomeres or in response to extra- or intracellular stress factors (Savale et al. 2009).

There is much evidence of common features between pulmonary emphysema and lung ageing as oxidative stress, inflammation and apoptosis are common for both (MacNee 2009). The number of ageing lung vascular endothelial cells is higher in COPD patients as it has been thought decreased telomerase activity and shortened telomeres are the main factor in this process (Amsellem et al. 2011).

Telomeres are specialized nucleoprotein structures at chromosome ends. In vertebrates they consist of tandem repeats of TTAGGG sequence stabilized by a complex of proteins, known as shelterin, protecting the natural chromosome termini from the DNA damage signaling and repair activities (Bertuch 2016; Birch et al. 2015). The critical minimum number of 12.8 telomere repeats is required to protect chromosome from recombination and fusion (Bernadotte et al. 2016). DNA replication is incomplete at the 3 'end of the linear chromosome, due to the end replication problem (Maubaret et al. 2013). Thus telomere length (TL) decreases 50 to 200 base pairs with each cell division until fter 50 to 60 cell cycles they reach the critical length (the Hayflick limit). As concequence, the cell cycle is interrupted resulting in the cellcycle arest and the cell undergoes apoptosis or becomes senescent (Aix et al. 2016; Alter et al. 2007; Bertuch 2016; Fumagalli et al. 2014; Maubaret et al. 2013). Telomeres can also be shortened as a result of DNA double-strand break damage (Bernadotte et al. 2016).

Telomere shortening is associated with organism aging, as leukocytes telomere length (LTL) is inversely related to age and is associated with increased risk of age-related diseases and with mortality (Soerensen et al. 2012). Telomerase is a specialized reverse transcriptase composed of catalytic protein (reverse transcriptase, TERT) and telomerase RNA component (TERC). The latter is the constituent of the enzyme, which provides the template for the synthesis of the TTAGGG repeats. The enzyme telomerase prevents the shortening of the telomeres by synthesizing telomeric repeats on to the end of the 3' G-rich strand. To prolong their growth capacity, highly dividing cells, such as stem cells, maintain high activity of this enzyme complex. A number of short nucleotide polymorphisms (SNPs) at loci encoding the main components of the telomerase genes, TERT and TERC have been shown to correlate with the TL (Bertuch 2016; Calado 2009; Maubaret et al. 2013; Schmidt \& Cech 2015).

It has been found that in COPD patients there is a low activity of the telomerase (Kordinas et al. 2016) and shorter telomeres of the chromosomes of the circulating leukocytes, alveolar epithelial cells and lung vascular endothelial cells (Amsellem et al. 2011; Houben et al. 2009; Savale et al. 2009), as well as of the senile smooth muscle cells in remodeled blood vessels (Morla et al. 2006). 
In this context, the identification of SNPs in the pathogenesis of COPD and the establishment of potential biomarkers like LTL for predicting clinical outcomes in COPD phenotypes would be helpful for personalizing the management the disease.

\section{Materials and methods}

\section{Patients and controls}

All together 194 patients with COPD and 281 non-affected control individuals from the region of Stara Zagora, Bulgaria, were included in our case-control study. The including criteria for the individuals with COPD was as described previously (Tacheva et al. 2017). The patients were recruited in the Clinic of Internal Medicine, University Hospital, Trakia University, Stara Zagora, Bulgaria from 2008 till 2011. Patients had different stages of the disease according to GOLD (GOLD II, III and IV). The inclusion criteria for COPD were: age higher than 40 years; forced expiratory volume in 1 second (FEV1) of $<80 \%$; forced expiratory volume in 1 second (FEV1)/forced vital capacity (FVC) ratio of $\leq 70 \%$; FEV1 reversibility after inhalation of Salbutamol $400 \mu \mathrm{g}$ of $<12 \%$.

The control group consisted of 281 healthy unaffected by any lung diseases volunteers from the same ethnic group and area of Bulgaria or individuals not affected by lung or cancer diseases collected.

The available demographic and clinical data of both COPD patients and control individuals are presented in Table 1.

The Ethics committee at Medical Faculty, Trakia University, Stara Zagora, Bulgaria has approved the study protocol and written informed consents were obtained from all participants before the study.

\section{Isolation of DNA}

For the isolation of genomic DNA a commercial kit (GenElute ${ }^{\mathrm{TM}}$ Mammalian Genomic DNA Miniprep Kit, Sigma, USA) was used. The purity of the isolated DNA and the concentration (in $\mathrm{ng} / \mu \mathrm{l}$ ) were assessed spectrophotometrically (NanoDrop Spectrophotometer ND-1000, Thermo Fisher Scientific - NanoDrop products, NanoDrop Technologies Inc). The purity was evaluated by calculating the ratio of the OD at $\lambda 260 \mathrm{~nm}$ and $\lambda 280 \mathrm{~nm}$.

\section{Genotyping}

The genotyping for TERC $\mathrm{C}>\mathrm{G}$ and $T E R C \mathrm{C}>\mathrm{T}$ SNP was performed by TaqMan q-PCR. The PCR mix contained 1.5 $\mu$ TaqMan Genotyping Master Mix (Applied Biosystems, USA), $0.1 \mu \mathrm{l} 40 \mathrm{x}$ SNP Genotyping assay with VIC ${ }^{\circledR}$ and FAM $^{\mathrm{TM}}$ dyes, $1 \mu \mathrm{l}$ genomic DNA $(10 \mathrm{ng} / \mu \mathrm{l})$ and distilled water up to the final volume of $4 \mu$ l. The reaction was performed with preliminary denaturation and activation of the polymerase for $2 \mathrm{~min}$ at $50^{\circ} \mathrm{C}$ and $10 \mathrm{~min}$ at $95^{\circ} \mathrm{C}$, followed by 40 cycles of denaturation at $95^{\circ} \mathrm{C}$ for $15 \mathrm{~s}$ (slope, $20^{\circ} \mathrm{C} / \mathrm{s}$ ), annealing and primer extension at $60^{\circ} \mathrm{C}$ for $1 \mathrm{~min}$. The data from the fluorescence of the both dyes were detected by 7900 Fast Real-Time PCR System (Applied Biosystems, USA). The Allele discrimination software was used for determining the genotypes of the studied persons.

\section{Leukocyte telomere length measurement}

The telomere length was measured using SYBR green qPCR method (O'Callaghan et al. 2008). The method is based on using a standard curve made of serial dilutions of a pTEL plasmid containing a 600 base pair long telomere sequence. The telomeres were amplified by using primers that bind to the telomere region of the template DNA. By using the standard curve, each sample is given a quantity, which corresponds to the amount of kilo bases of telomere sequence in the reaction. Fth1 was used as a reference gene. 
The DNA samples were diluted to a final concentration of $0.5 \mathrm{ng} / \mu 1$. For each reaction, 2 $\mu 1 \mathrm{DNA}, 5 \mu \mathrm{l}$ SYBR green, $2.6 \mu 1 \mathrm{H}_{2} \mathrm{O}$, and $0.2 \mu \mathrm{l}$ of each primer were mixed to a total of $10 \mu \mathrm{l}$ per well, and the samples were run as duplicates. The thermocycler that was used was Applied Biosystems' 7900 real-time machine. The thermal profile of the qPCR reaction was as follows: preliminary denaturation and activation of the polymerase at $95^{\circ} \mathrm{C}$ for $2 \mathrm{~min}$, followed by 40 cycles of denaturation at $95^{\circ} \mathrm{C}$ for $10 \mathrm{sec}$ and annealing and primer extension at $60^{\circ} \mathrm{C}$ for $45 \mathrm{sec}$, with a dissociation-curve: $95^{\circ} \mathrm{C}$ for $15 \mathrm{sec}, 60^{\circ} \mathrm{C}$ for $15 \mathrm{sec}, 95^{\circ} \mathrm{C}$ for $15 \mathrm{sec}$.

\section{Statistical analyses}

Statistical analyses were performed using SPSS 16.0 for Windows (IBM, Chicago,IL). The continuous variables with normal distribution were compared between two or more independent groups by Student t-test or One-way ANOVA test with LSD Post hoc analysis, while those variables with non-normal distribution were compared by using Mann-Whitney U test or Kruskal-Wallis H test, respectively. The correlations between the continuous variables were assessed using the Pearson or Spearman correlation tests according to the type of the variables' distribution.

By using the $\chi 2$ test, the genotype distributions of control individuals and COPD patients were tested for deviation from Hardy-Weinberg equilibrium (HWE). The differences in genotype and allele distributions between the groups were analyzed in $2 \times 2$ or $2 \times 3$ contingency tables with $\chi 2$ test. Binary Logistic regression was used for calculation of the odds ratios (OR) and $95 \%$ confidence interval $(\mathrm{CI})$ with age and sex as covariates. Factors with $\mathrm{p}<0.05$ were considered statistically significant.

\section{Results}

\section{TERC rs12696304 (C>G) SNP}

The genotype frequencies according to $\mathrm{rs} 12696304(\mathrm{C}>\mathrm{G})$ promoter polymorphism in both groups did not deviate from Hardy-Weinberg equilibrium ( $\mathrm{p}=0.953$ for COPD patients and $\mathrm{p}=0.531$ for the control individuals).

In the genotype distribution we found statistical difference between controls and COPD patients ( $p=0.035, \chi^{2}$ test). The genotype frequencies of both groups are presented in Table 2 . In the allele distribution there was also significant difference $(p=0.019$, Table 2$)$. The results of the logistic regression analysis showed that the carriers of CG genotype have 1.58-fold lower risk of developing COPD compared to the individuals with homozygous $\mathrm{CC}$ genotypes $(\mathrm{p}=0.020$, Table 2). The significance remained also after adjustment for sex and age ( $\mathrm{p}=0.028$, Table 2$)$. In the recessive model, the carriers of genotypes containing at least one variant $\mathrm{G}$ allele $(\mathrm{CG}+\mathrm{GG})$ had 1.63-fold lower risk of COPD than those with CC genotypes ( $\mathrm{p}=0.011$, Table 2$)$. The significance remained also after adjustment for sex and age $(\mathrm{p}=0.022$, Table 2$)$.

\section{TERC C $>$ T (rs10936599) SNP}

The genotype distribution according to TERC C $>\mathrm{T}$ (rs10936599) SNP was in equilibrium with the Hardy-Weinberg principle ( $\mathrm{p}=0.272$ for controls and $\mathrm{p}=0.808$ for COPD patients). The frequency of genotypes in control individuals and COPD patient can be seen in Table 3 . The genotype distribution in COPD patients did not differ from that in controls ( $\mathrm{p}=0.113$, Table 3 ). A marginal difference was found in the allele distribution - the variant $\mathrm{T}$ allele was more common in controls than in patients ( $p=0.058$, Table 3 )

The carriers of the more common homozygous CC genotype had 1.5-fold higher risk for COPD compared to the heterozygous $(\mathrm{p}=0.045)$ and than those carrying the variant $\mathrm{T}$ allele $(\mathrm{CT}+\mathrm{TT})(\mathrm{p}=0.044$, Table 3$)$. 
Analysis on the combined effects of the TERC rs12696304 $(\mathrm{C}>\mathrm{G})$ and rs10936599 $(\mathrm{C}>\mathrm{T})$ genotypes on the development of COPD showed that, individuals who are carriers simultaneously of CC/CC genotypes have 1.98-fold higher risk for COPD compared to persons having all other genotype combinations $(\mathrm{p}<0.0001)$ (Table 4$)$. This very strong significance remained also after adjustment for gender and age $(\mathrm{p}=0.001)$ (Table 4$)$. The spirometric indices of the patients carrying $\mathrm{CC} / \mathrm{CC}$ genotypes did not differ significantly than those with all other genotype combinations (FEV1\% pr. 50.35 \pm 1.34 (SEM) vs. 53.05 \pm 1.52 (SEM), p=0.185; FEV1/FVC $61.61 \pm 0.86$ (SEM) vs. $61.00 \pm 0.93$ (SEM), p=0.626). However, when the patients were dichotomized into two groups (GOLD stage II and GOLD stage III/IV) we found that $\mathrm{CC} / \mathrm{CC}$ genotype combination was associated with marginally lower FEV1\% pr. than the other genotype combinations only in patients with moderate COPD (GOLD II) $(58.87 \pm 1.10$ (SEM) vs. $62.45 \pm 1.46, \mathrm{p}=0.052)$. Such difference was not observed between the genotype carriers in patients with severe/very severe COPD (GOLD stage III/IV), (39.00 \pm 1.35 (SD) vs. 40.75 \pm 1.54 , $\mathrm{p}=0.364)$.

\section{Leukocyte telomere length}

Comparison of the leukocyte telomeres showed that they are shorter in COPD patients compared to controls, but without significant difference (17919.36 \pm 1203.01 (SEM) bp vs. $21271.48 \pm 1891.36$ (SEM) bp, $\mathrm{p}=0.137$ ) (Fig. 1). When splitting controls and COPD patients into two subgroups - less than and above 60 years of age, we found near-marginal significance for shorter telomeres in COPD patients above 60 years compared to controls in the same subgroup (17558.73 \pm 1536.78 (SEM) bp vs. 22257.88 3684.15 (SEM) bp., p=0.188, Figure 2), but no difference was seen in younger subgroups $(\mathrm{p}=0.479)$.

In COPD patients we found no differences in the LTL in different GOLD stages $(p=0.468$, ANOVA test). There were also no statistically significant correlations between the LTL and age $(p=0.903)$, age of disease diagnosis $(p=0.962)$ and spirometric indices of the lung function FEV1\% ( $p=0.814)$ and FEV1/FVC\% $(p=0.631)$. LTL did not differ between the male and female COPD patients $(\mathrm{p}=0.169)$, as well as when compared between the patients with different BMI (normal BMI vs. overweight vs. obese, $p=0.398$ ). Similarly, in control group, LTL did not differ between sexes $(p=0.835)$, and did not correlate with the age $(p=0.759)$ and spirometric indices ( $\mathrm{p}=0.991$ for FEV1\% $\mathrm{pr}$, and $\mathrm{p}=0.419$ for FEV1/FVC). There was only a tendency for a weak negative correlation between LTL and BMI in controls $(\mathrm{Rho}=-0.215$, $\mathrm{p}=0.076$ ). When the LTL were compared between the controls with normal BMI vs. overweight vs. obese, in the LSD post hoc analysis of ANOVA test the obese controls had marginally lower LTL (14752.22 \pm 2938.48 (SEM) bp) than the controls with normal BMI (23008.93 \pm 1867.79 (SEM) bp, $\mathrm{p}=0.091$ ).

Unexpectedly, the smoking habits did not influence the LTL either in patients (current smokers: $17238.96 \pm 2853.24$ (SEM) bp vs. ex-smokers: 19214.10 \pm 1790.28 (SEM) bp vs. nonsmokers: $16700.79 \pm 2127.42$ (SEM) bp, $\mathrm{p}=0.644$, ANOVA test) or in controls (current smokers: 19393.32 \pm 2965.92 (SEM) bp. vs. ex-smokers: 17999.97 3160.78 (SEM) bp. vs. non-smokers: $22676.26 \pm 3086.59$ (SEM) bp., p=0.712, ANOVA test). In COPD patients aged above 60 years which also are current/ex-smokers, telomeres were shorter in man compared to women (14909 \pm 1957.87 (SEM) bp vs. $30925 \pm 6818.35$ (SEM) bp, p=0.006).

We found no association between LTL and the studied polymorphisms rs12696304 and rs10936599 near TERC, both in controls and COPD patients (Table 5)

\section{Discussion}


In our study, we found shorter LTL in patients with COPD, even though without significance. The absence of statistical difference might be due to the small number of both groups (88 control individuals and 91 patients with COPD). Nevertheless our results are with accordance to others where it has been found an association of telomere shortening with COPD in circulating leukocytes (Savale et al. 2009), alveolar epithelial cells (Houben et al. 2009; Mui et al. 2009), and pulmonary vascular endothelial cells (Amsellem et al. 2011). In addition shorter telomeres in the lungs of individuals with emphysema and pulmonary fibrosis have been found when compared with unaffected individuals (Alder et al. 2015; Alder et al. 2011; Tsuji et al. 2006).

Human leukocytes telomeres have been shown to decrease approximately with 20-30 bp per year in vivo (Daniali L et al. 2013). Besides genetic factors there are variety of environmental and behavior ones (tobacco smoking, diet, stress, air pollution etc.) which have influence on leukocytes telomere (Liu et al. 2019). Many of these factors have been shown to be associated with higher risk of COPD.

It seems in our groups those factors do not independently have an impact on LTL but when combining they may reflect on the length of the telomeres. Although our subgroup in this case is quite small we found significantly shorter telomeres in male current/ex-smokers COPD patients above 60 years than female from the same subgroup. Besidest smoking it has been show that sex might also be an important factor in telomere shortening. Longer telomeres in women might be due to estrogen which by binding to estrogen response element in the hTERT promoter region contribute to telomere restoration (Mayer et al. 2006). It has been found that oxidative stress also plays role in telomere shortening. By reducing the production of ROS and being a potent antioxidant and regulator of antioxidant genes, estrogen might affect the TL(Lulkiewicz et al. 2020).

It is known that in COPD oxidative stress is of great importance for the disease development and progression. Several animal and in vitro models have shown that chronic oxidative stress induces an accelerated rate of telomere loss. Other pathological conditions such as atherosclerosis, diabetes type I (Houben et al. 2009) cardiovascular disease (Fitzpatrick et al. 2011), renal failure (Boxall et al. 2006), various cancers (Broberg et al. 2005), Alzheimer's disease (Cai et al. 2013), and Parkinson's disease (Maeda et al. 2012) have been related to constant high level of oxidative stress and chronic inflammation and linked with telomere shortening (Kordinas et al. 2016). Additionally, telomere length can be dynamically changed throughout an individual's life period in response to environmental factors and stress (Aviv 2002; Carlson et al. 2015).

The process of senescence in somatic cells occurs in result of depletion of the replicative potential or in response to excessive extracellular or intracellular stress (Campisi \& d'Adda di Fagagna 2007), as both forms of senescence may be present in COPD (Savale et al. 2009; Tsuji et al. 2004).

Amsellem et. al. have found increased number senescent smooth muscle cells in the media of remodeled vessels from patients with COPD. Premature senescence in COPD has been associated with overexpression of pro-inflammatory cytokines and adhesion molecules, together with shortened telomeres (Amsellem et al. 2011).

In their study Alder et.al. highlight the contrast in the response to telomere dysfunction between high- and low turnover tissues (Alder et al. 2015). Similarly, human telomere-mediated lung diseases become symptomatic in late adulthood, reflecting a slower development of the process (Parry et al. 2011). 
The senescence is associated with accumulation of cyclin-dependent kinase inhibitors (Tsuji et al. 2006). Telomeric signals are mediated mainly by the p53-p21 pathway and nontelomeric signals by the p16-retinoblastoma protein pathway (Campisi \& d'Adda di Fagagna 2007). In the lungs of patients with emphysema increased numbers of p21- and p16-stained cells have been found (Amsellem et al. 2011). Dysfunctional telomeres activate a DNA damage response, trigger the formation of anaphase bridges, and up-regulate the cell-cycle inhibitor p2 1 (Aix et al. 2016).

Alterations of airway epithelium, including squamous cell metaplasia, goblet and basal cell hyperplasia, are often present in smokers with COPD. Differentiation of variety of tissue types, including squamous epithelia, is associated with an increased p21Wafl expression. The cytoplasmic and nuclear p-21 immunoreactivity has been found significantly increased in COPD smokers compared to controls (Chiappara et al. 2013).In contrast to our results, Birch et.al. failed to detect differences in TL between controls and patients with COPD (Birch et al. 2015) Consistently, another study also failed to find differences in TL between lung fibroblasts isolated from patients with emphysema and aged-matched controls, despite increased expression of senescence-associated markers (Muller et al. 2006). Interestingly, it has been found that the median telomere length is longer in peripheral blood leukocytes from COPD patients with a1antitrypsin deficiency compared with COPD controls (Saferali et al. 2014).

The differences in the results reported in variety of studies on TL in chronic lung diseases might be due to the different methods used for telomere length measurement. On the other hand the length of telomeres varies between individuals and the different cells and chromosomes in the same person. Another fact that should not be underestimated is that LTL might be altered by therapeutic interventions (Lulkiewicz et al. 2020).

After all the factors (endogenous mechanisms and exogenous factors) resulting in TL changes are quite diverse and many studies should be done in order to understand the exact mechanism of TL regulation.

Some common SNPs near TERC have been found to be involved in telomere biology including rs12696304 $(C>G)$ and rs10936599 (C>T) (Codd et al. 2010; Codd et al. 2013; Levy et al. 2010; Shen et al. 2011; Vasa-Nicotera et al. 2005). In a genome-wide association study of mean leukocyte telomere length in 2,917 individuals, it has been found that each rs12696304(G) allele is significantly associated with reduction in the mean telomere length (Codd et al. 2010). The minor alleles for both SNPs have been found to negatively correlate with LTL. (Michalek et al. 2017; Soerensen et al. 2012).

Interestingly, opposite to our findings of shorter LTL in patients with COPD, we obtained higher frequency of the referent allele of both SNPs (rs12696304 and rs10936599) in the patients group. It appeared that those genotypes containing the variant allele (rs12696304 CG+GG and rs 10936599 CT+TT) are protective. The results on the role of rs12696304 and rs10936599 SNPs in chronic inflammatory diseases, which we can compare ours with, are quite diverse and ambiguous. For example, in unison with our findings of higher frequency of the referent allele in the group of patients, a significant association of the major allele (C) of rs10936599 with the high risk for type 2 diabetes has been reported (Sethi et al. 2020). On the other hand in a study of the associations of TERC SNPs with LTL and the risk of type 2 diabetes mellitus in Kuwaiti population it has been found that homozygous carries of less common allele (G) of rs12696304 have shorter LTL compared with other genotypes. Besides having the shortest LTL homozygous carriers of the minor allele G appeared to have significantly lower hTERT serum levels and highest insulin resistance compared to the other two genotypes. (Al Khaldi R et al. 2015). 
310 Similar findings for shorter telomeres in carriers of the minor G allele of rs 12696304 have been

311

312

313

314

315

316

317

318

319

320

321

322

323

324

325

326

327

328

329

330

331

332

333

334

335

336

337

338

339

340

341

342

343

344

345

346

347

348

349

350

351

352

353

354

355

356

reported in European, American and Chinese Han populations (Codd et al. 2010)

Higher frequency of rs $12696304 \mathrm{G}$ allele have been found in individuals with chronic kidney disease with no difference of LTL among different genotypes (Sun et al. 2020).

In another chronic inflammatory lung disease - Coal workers' pneumoconiosis and in Coronary heart disease (CHD) no association with rs12696304 and rs10936599 SNPs has been found (Maubaret et al. 2013; Yuan et al. 2020).

It is clear that in most of the studies the minor alleles are related to shorter telomeres and pathogenesis and clinical outcomes of chronic inflammatory diseases. Still, the presence of reports showing no association of the genotype with the TL in chronic diseases suggest that other mechanisms might play role in the regulation of telomere length.

In telomerase-null mice, DNA damage appears in the air-exposed epithelium after environmentally induced injury (cigarette smoke for example). The additive effect of environmental injury and telomere dysfunction has been suggested to contribute to the susceptibility to emphysema seen in these mice (Alder et al. 2015).

In addition histone methylation in the telomere region and demethylation of the human TERT both play significant role in maintaining heterochromatin, transcription silencing at telomeres, and telomerase inactivation (Bernadotte et al. 2016).

According to our study, the mean LTL is shorter in patients with COPD, but it is not related to the genotype. Perhaps, other factors which play role in the development of the disease (chronic inflammation and oxidative stress), may influence the telomere length. Because the main limitation of the present study is the small sample size of both COPD and controls groups, more studies with significantly bigger in size groups have to be done in order to reveal the role of telomeres and the polymorphisms in TERC in the development and progression of COPD.

\section{Funding}

The present study was supported by project 3/2019 of the Medical Faculty, Trakia University, (Stara Zagora, Bulgaria)

\section{Competing interests}

The authors declare that they have no competing interests and no conflicts of interest in connection with this paper. The material described is not under publication or consideration for publication elsewhere and it will not be published elsewhere in the same form without the written consent of the copyright-holder.

\section{References}

Aix E, Gutierrez-Gutierrez O, Sanchez-Ferrer C, Aguado T, and Flores I. 2016. Postnatal telomere dysfunction induces cardiomyocyte cell-cycle arrest through $\mathrm{p} 21$ activation. $\mathrm{J}$ Cell Biol 213:571-583.

Al Khaldi R, Mojiminiyi O, AlMulla F, and Abdella N. 2015. Associations of TERC Single Nucleotide Polymorphisms with Human Leukocyte Telomere Length and the Risk of Type 2 Diabetes Mellitus. PLoS One 10:e0145721. doi: 0145710.0141371/journal.pone.0145721. eCollection 0142015.

Alder JK, Barkauskas CE, Limjunyawong N, Stanley SE, Kembou F, Tuder RM, Hogan BL, Mitzner W, and Armanios M. 2015. Telomere dysfunction causes alveolar stem cell failure. Proc Natl Acad Sci U S A 112:5099-5104.

PeerJ reviewing PDF | (2021:02:57897:1:1:NEW 16 Aug 2021) 
357

358

359

360

361

362

363

364

365

366

367

368

369

370

371

372

373

374

375

376

377

378

379

380

381

382

383

384

385

386

387

388

389

390

391

392

393

394

395

396

397

398

399

400

401

Alder JK, Guo N, Kembou F, Parry EM, Anderson CJ, Gorgy AI, Walsh MF, Sussan T, Biswal S, Mitzner W, Tuder RM, and Armanios M. 2011. Telomere length is a determinant of emphysema susceptibility. Am J Respir Crit Care Med 184:904-912.

Alter BP, Baerlocher GM, Savage SA, Chanock SJ, Weksler BB, Willner JP, Peters JA, Giri N, and Lansdorp PM. 2007. Very short telomere length by flow fluorescence in situ hybridization identifies patients with dyskeratosis congenita. Blood 110:1439-1447.

Amsellem V, Gary-Bobo G, Marcos E, Maitre B, Chaar V, Validire P, Stern JB, Noureddine H, Sapin E, Rideau D, Hue S, Le Corvoisier P, Le Gouvello S, Dubois-Rande JL, Boczkowski J, and Adnot S. 2011. Telomere dysfunction causes sustained inflammation in chronic obstructive pulmonary disease. Am J Respir Crit Care Med 184:1358-1366.

Aviv A. 2002. Telomeres, sex, reactive oxygen species, and human cardiovascular aging. J Mol Med 80:689-695.

Bernadotte A, Mikhelson VM, and Spivak IM. 2016. Markers of cellular senescence. Telomere shortening as a marker of cellular senescence. Aging 8:3-11.

Bertuch AA. 2016. The molecular genetics of the telomere biology disorders. RNA Biol 13:696706.

Birch J, Anderson RK, Correia-Melo C, Jurk D, Hewitt G, Marques FM, Green NJ, Moisey E, Birrell MA, Belvisi MG, Black F, Taylor JJ, Fisher AJ, De Soyza A, and Passos JF. 2015. DNA damage response at telomeres contributes to lung aging and chronic obstructive pulmonary disease. Am J Physiol Lung Cell Mol Physiol 309:18.

Boxall MC, Goodship TH, Brown AL, Ward MC, and von Zglinicki T. 2006. Telomere shortening and haemodialysis. Blood Purif 24:185-189.

Broberg K, Bjork J, Paulsson K, Hoglund M, and Albin M. 2005. Constitutional short telomeres are strong genetic susceptibility markers for bladder cancer. Carcinogenesis 26:12631271.

Cai Z, Yan LJ, and Ratka A. 2013. Telomere shortening and Alzheimer's disease. Neuromolecular Med 15:25-48.

Calado RT. 2009. Telomeres and marrow failure. Hematology Am Soc Hematol Educ Program:338.

Campisi J, and d'Adda di Fagagna F. 2007. Cellular senescence: when bad things happen to good cells. Nat Rev Mol Cell Biol 8:729-740.

Carlson LE, Beattie TL, Giese-Davis J, Faris P, Tamagawa R, Fick LJ, Degelman ES, and Speca M. 2015. Mindfulness-based cancer recovery and supportive-expressive therapy maintain telomere length relative to controls in distressed breast cancer survivors. Cancer 121:476484.

Chiappara G, Gjomarkaj M, Virzi A, Sciarrino S, Ferraro M, Bruno A, Montalbano AM, Vitulo P, Minervini MI, Pipitone L, and Pace E. 2013. The role of p21 Waf1/Cip1 in large airway epithelium in smokers with and without COPD. Biochim Biophys Acta 2013:1473-1481.

Chung KF, and Adcock IM. 2008. Multifaceted mechanisms in COPD: inflammation, immunity, and tissue repair and destruction. Eur Respir J 31:1334-1356.

Codd V, Mangino M, van der Harst P, Braund PS, Kaiser M, Beveridge AJ, Rafelt S, Moore J, Nelson C, Soranzo N, Zhai G, Valdes AM, Blackburn H, Mateo Leach I, de Boer RA, Kimura M, Aviv A, Goodall AH, Ouwehand W, van Veldhuisen DJ, van Gilst WH, Navis G, Burton PR, Tobin MD, Hall AS, Thompson JR, Spector T, and Samani NJ.

PeerJ reviewing PDF | (2021:02:57897:1:1:NEW 16 Aug 2021) 
2010. Common variants near TERC are associated with mean telomere length. Nat Genet 42:197-199.

Codd V, Nelson CP, Albrecht E, Mangino M, Deelen J, Buxton JL, Hottenga JJ, Fischer K, Esko T, Surakka I, Broer L, Nyholt DR, Mateo Leach I, Salo P, Hagg S, Matthews MK, Palmen J, Norata GD, O'Reilly PF, Saleheen D, Amin N, Balmforth AJ, Beekman M, de Boer RA, Bohringer S, Braund PS, Burton PR, de Craen AJ, Denniff M, Dong Y, Douroudis K, Dubinina E, Eriksson JG, Garlaschelli K, Guo D, Hartikainen AL, Henders AK, Houwing-Duistermaat JJ, Kananen L, Karssen LC, Kettunen J, Klopp N, Lagou V, van Leeuwen EM, Madden PA, Magi R, Magnusson PK, Mannisto S, McCarthy MI, Medland SE, Mihailov E, Montgomery GW, Oostra BA, Palotie A, Peters A, Pollard H, Pouta A, Prokopenko I, Ripatti S, Salomaa V, Suchiman HE, Valdes AM, Verweij N, Vinuela A, Wang X, Wichmann HE, Widen E, Willemsen G, Wright MJ, Xia K, Xiao X, van Veldhuisen DJ, Catapano AL, Tobin MD, Hall AS, Blakemore AI, van Gilst WH, Zhu H, Erdmann J, Reilly MP, Kathiresan S, Schunkert H, Talmud PJ, Pedersen NL, Perola M, Ouwehand W, Kaprio J, Martin NG, van Duijn CM, Hovatta I, Gieger C, Metspalu A, Boomsma DI, Jarvelin MR, Slagboom PE, Thompson JR, Spector TD, van der Harst P, and Samani NJ. 2013. Identification of seven loci affecting mean telomere length and their association with disease. Nat Genet 45:422-427.

Daniali L, Benetos A, Susser E, Kark Jd, Labat C, Kimura M, Desai K, Granick M, and Aviv A. 2013. Telomeres shorten at equivalent rates in somatic tissues of adults. Nat Commun 4:1597. doi: $1510.1038 /$ ncomms2602.

Fitzpatrick AL, Kronmal RA, Kimura M, Gardner JP, Psaty BM, Jenny NS, Tracy RP, Hardikar S, and Aviv A. 2011. Leukocyte telomere length and mortality in the Cardiovascular Health Study. J Gerontol A Biol Sci Med Sci 66:421-429.

Fumagalli M, Rossiello F, Mondello C, and d'Adda di Fagagna F. 2014. Stable cellular senescence is associated with persistent DDR activation. PLoS One 9:2014.

GOLD. 2017. Global strategy for the diagnosis, management, and prevention of chronic obstructive pulmonary disease 2017 report.

Houben JM, Mercken EM, Ketelslegers HB, Bast A, Wouters EF, Hageman GJ, and Schols AM. 2009. Telomere shortening in chronic obstructive pulmonary disease. Respir Med 103:230-236.

Kordinas V, Ioannidis A, and Chatzipanagiotou S. 2016. The Telomere/Telomerase System in Chronic Inflammatory Diseases. Cause or Effect? Genes 7.

Lange P, Halpin DM, O'Donnell DE, and MacNee W. 2016. Diagnosis, assessment, and phenotyping of COPD: beyond FEV1. Int J Chron Obstruct Pulmon Dis 11 3-12, DOI: 10.2147/COPD.S85976.

Levy D, Neuhausen SL, Hunt SC, Kimura M, Hwang SJ, Chen W, Bis JC, Fitzpatrick AL, Smith E, Johnson AD, Gardner JP, Srinivasan SR, Schork N, Rotter JI, Herbig U, Psaty BM, Sastrasinh M, Murray SS, Vasan RS, Province MA, Glazer NL, Lu X, Cao X, Kronmal R, Mangino M, Soranzo N, Spector TD, Berenson GS, and Aviv A. 2010. Genome-wide association identifies OBFC1 as a locus involved in human leukocyte telomere biology. Proc Natl Acad Sci U S A 107:9293-9298.

Liu B, Maekawa T, Yoshida K, Ly NH, Inoue K, Hasegawa A, Chatton B, Ogura A, and Ishii S. 2019. Telomere shortening by transgenerational transmission of TNF-O \pm -induced TERRA via ATF7. Nucleic Acids Res 47:283-298. doi: 210.1093/nar/gky1149. 
447

448

449

450

451

452

453

454

455

456

457

458

459

460

461

462

463

464

465

466

467

468

469

470

471

472

473

474

475

476

477

478

479

480

481

482

483

484

485

486

487

488

489

490

491

492

Lulkiewicz M, Bajsert J, Kopczynski P, Barczak W, and Rubis B. 2020. Telomere length: how the length makes a difference. Mol Biol Rep 47:7181-7188. doi: 7110.1007/s1103311020-05551-y.

MacNee W. 2009. Accelerated lung aging: a novel pathogenic mechanism of chronic obstructive pulmonary disease (COPD). Biochem Soc Trans 37:819-823.

Maeda T, Guan JZ, Koyanagi M, Higuchi Y, and Makino N. 2012. Aging-associated alteration of telomere length and subtelomeric status in female patients with Parkinson's disease. J Neurogenet 26:245-251.

Maubaret CG, Salpea KD, Romanoski CE, Folkersen L, Cooper JA, Stephanou C, Li KW, Palmen J, Hamsten A, Neil A, Stephens JW, Lusis AJ, Eriksson P, Talmud PJ, and Humphries SE. 2013. Association of TERC and OBFC1 haplotypes with mean leukocyte telomere length and risk for coronary heart disease. PLoS One 8:2013.

Mayer S, BrГjderlein S, Perner S, Waibel I, Holdenried A, Ciloglu N, Hasel C, Mattfeldt T, Nielsen KV, and MГ $\mid 11$ rer P. 2006. Sex-specific telomere length profiles and agedependent erosion dynamics of individual chromosome arms in humans. Cytogenet Genome Res 112:194-201. doi: 110.1159/000089870.

Michalek JE, Kepa A, Vincent J, Frissa S, Goodwin L, Hotopf M, Hatch SL, Breen G, and Powell TR. 2017. Genetic predisposition to advanced biological ageing increases risk for childhood-onset recurrent major depressive disorder in a large UK sample. J Affect Disord 213:207-213.

Morla M, Busquets X, Pons J, Sauleda J, MacNee W, and Agusti AG. 2006. Telomere shortening in smokers with and without COPD. Eur Respir J 27:525-528.

Mui TS, Man JM, McElhaney JE, Sandford AJ, Coxson HO, Birmingham CL, Li Y, Man SF, and Sin DD. 2009. Telomere length and chronic obstructive pulmonary disease: evidence of accelerated aging. J Am Geriatr Soc 57:2372-2374.

Muller KC, Welker L, Paasch K, Feindt B, Erpenbeck VJ, Hohlfeld JM, Krug N, Nakashima M, Branscheid D, Magnussen H, Jorres RA, and Holz O. 2006. Lung fibroblasts from patients with emphysema show markers of senescence in vitro. Respir Res 7:32.

O'Callaghan N, Dhillon V, Thomas P, and Fenech M. 2008. A quantitative real-time PCR method for absolute telomere length. Biotechniques 44:807-809.

Parry EM, Alder JK, Qi X, Chen JJ, and Armanios M. 2011. Syndrome complex of bone marrow failure and pulmonary fibrosis predicts germline defects in telomerase. Blood 117:56075611.

Pauwels RA, and Rabe KF. 2004. Burden and clinical features of chronic obstructive pulmonary disease (COPD). Lancet 364:613-620.

Saferali A, Lee J, Sin DD, Rouhani FN, Brantly ML, and Sandford AJ. 2014. Longer telomere length in COPD patients with alpha1-antitrypsin deficiency independent of lung function. PLoS One 9:2014.

Savale L, Chaouat A, Bastuji-Garin S, Marcos E, Boyer L, Maitre B, Sarni M, Housset B, Weitzenblum E, Matrat M, Le Corvoisier P, Rideau D, Boczkowski J, Dubois-Rande JL, Chouaid C, and Adnot S. 2009. Shortened telomeres in circulating leukocytes of patients with chronic obstructive pulmonary disease. Am J Respir Crit Care Med 179:566-571.

Schmidt JC, and Cech TR. 2015. Human telomerase: biogenesis, trafficking, recruitment, and activation. Genes Dev 29:1095-1105.

Sethi I, Sharma V, Sharma I, Singh G, Bhat GR, Bhanwer AJS, Sharma S, and Rai E. 2020. Telomere Maintenance Genes are associated with Type 2 Diabetes Susceptibility in 
Northwest Indian Population Group. Sci Rep 10:6444. doi: 6410.1038/s41598-4102063510-w.

Shen Q, Zhang Z, Yu L, Cao L, Zhou D, Kan M, Li B, Zhang D, He L, and Liu Y. 2011. Common variants near TERC are associated with leukocyte telomere length in the Chinese Han population. Eur J Hum Genet 19:721-723.

Soerensen M, Thinggaard M, Nygaard M, Dato S, Tan Q, Hjelmborg J, Andersen-Ranberg K, Stevnsner T, Bohr VA, Kimura M, Aviv A, Christensen K, and Christiansen L. 2012. Genetic variation in TERT and TERC and human leukocyte telomere length and longevity: a cross-sectional and longitudinal analysis. Aging Cell 11:223-227.

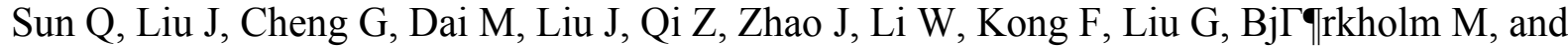
$\mathrm{Xu}$ D. 2020. The telomerase gene polymorphisms, but not telomere length, increase susceptibility to primary glomerulonephritis/end stage renal diseases in females. J Transl Med 18:184. doi: 110.1186/s12967-12020-02347-12963.

Tacheva T, Dimov D, Aleksandrova E, Bialecka M, Gulubova M, and Vlaykova T. 2017. The G allele of MMP12 -82 A $>$ G promoter polymorphism as a protective factor for COPD in Bulgarian population. Arch Physiol Biochem 123:371-376.

Tsuji T, Aoshiba K, and Nagai A. 2004. Cigarette smoke induces senescence in alveolar epithelial cells. Am J Respir Cell Mol Biol 31:643-649.

Tsuji T, Aoshiba K, and Nagai A. 2006. Alveolar cell senescence in patients with pulmonary emphysema. Am J Respir Crit Care Med 174:886-893.

Vasa-Nicotera M, Brouilette S, Mangino M, Thompson JR, Braund P, Clemitson JR, Mason A, Bodycote CL, Raleigh SM, Louis E, and Samani NJ. 2005. Mapping of a major locus that determines telomere length in humans. Am J Hum Genet 76:147-151.

Yuan B, Wen X, Li L, Li Y, Li C, Li B, Yuan W, and Cui L. 2020. NAF1 rs4691896 Is Significantly Associated with Coal Workers' Pneumoconiosis in a Chinese Han Population: A Case-Control Study. Med Sci Monit 26:e918709. doi: 918710.912659/MSM.918709. 
Table $\mathbf{1}$ (on next page)

Demographic and clinical data of COPD patients and controls. 


\begin{tabular}{|c|c|c|c|c|c|c|}
\hline & \multicolumn{3}{|c|}{ COPD patients } & \multicolumn{3}{|l|}{ Controls } \\
\hline & $\begin{array}{l}\text { rs12696304 } \\
(\mathrm{C}>\mathrm{G})\end{array}$ & $\begin{array}{l}\text { rs } 10936599 \\
(\mathrm{C}>\mathrm{T})\end{array}$ & LTL & $\begin{array}{l}\text { rs12696304 } \\
(\mathrm{C}>\mathrm{G})\end{array}$ & $\begin{array}{l}\text { rs10936599 } \\
(\mathrm{C}>\mathrm{T})\end{array}$ & LTL \\
\hline $\begin{array}{r}\text { males } \\
\text { females }\end{array}$ & $\begin{array}{l}(n=189) \\
142(75.1 \%) \\
47(24.9 \%)\end{array}$ & $\begin{array}{l}(n=191) \\
143(74.9 \%) \\
48(25.1 \%)\end{array}$ & $\begin{array}{l}(\mathrm{n}=91) \\
67(73.6 \%) \\
24(26.4 \%) \\
\end{array}$ & $\begin{array}{l}(n=277) \\
128(46.2 \%) \\
149(53.8 \%)\end{array}$ & $\begin{array}{l}(n=263) \\
121(46 \%) \\
142(54 \%)\end{array}$ & $\begin{array}{l}(\mathrm{n}=88) \\
38(43.2 \%) \\
50(56.8 \%)\end{array}$ \\
\hline $\begin{array}{l}\text { Age at the } \\
\text { inclusion in the } \\
\text { study } \\
\text { median(range) } \\
\text { (years) }\end{array}$ & $67(36-88)$ & $67(36-88)$ & $66(40-88)$ & $57(19-86)$ & $56(19-86)$ & $57(23-79)$ \\
\hline $\begin{array}{l}\text { Age at the } \\
\text { diagnosis of the } \\
\text { disease } \\
\text { median (range) } \\
\text { (years) }\end{array}$ & $64(30-86)$ & $62(30-86)$ & 63 & & & \\
\hline $\begin{array}{l}\text { Duration of the } \\
\text { disease } \\
\text { mean } \pm \mathrm{SD} \text { (years) } \\
\text { median (range) } \\
\text { (years) }\end{array}$ & $\begin{array}{l}4.9 \pm 5.4 \\
3(0-30)\end{array}$ & $\begin{array}{l}4.9 \pm 5.4 \\
3(0-30)\end{array}$ & $\begin{array}{l}4.7 \pm 4 \\
3.5(0-20)\end{array}$ & & & \\
\hline $\begin{array}{r}\text { Smoking status } \\
\text { non-smokers } \\
\text { ex-smokers } \\
\text { current smokers } \\
\end{array}$ & $\begin{array}{l}(n=185) \\
54(29.2 \%) \\
87(47.0 \%) \\
44(23.8 \%) \\
\end{array}$ & $\begin{array}{l}(\mathrm{n}=192) \\
55(28.6 \%) \\
89(46.4 \%) \\
48(25 \%) \\
\end{array}$ & $\begin{array}{l}(\mathrm{n}=89) \\
29(32.6 \%) \\
41(46.1 \%) \\
19(21.3 \%) \\
\end{array}$ & $\begin{array}{l}(n=191) \\
113(59.2 \%) \\
30(15.7 \%) \\
48(25.1 \%) \\
\end{array}$ & $\begin{array}{l}(n=186) \\
110(59.1 \%) \\
28(15.1 \%) \\
48(25.8 \%) \\
\end{array}$ & $\begin{array}{l}(\mathrm{n}=73) \\
47(64.4 \%) \\
7(9.6 \%) \\
19(26 \%) \\
\end{array}$ \\
\hline $\begin{array}{l}\text { Smoking habits } \\
\text { (packs/year) } \\
\text { mean } \pm \text { SD (years) } \\
\text { median (range) }\end{array}$ & $\begin{array}{l}31.8 \pm 15.2 \\
30(5-88)\end{array}$ & $\begin{array}{l}31.8 \pm 15.2 \\
30(5-88)\end{array}$ & $\begin{array}{l}29.2 \pm 14 \\
30(5-60)\end{array}$ & $\begin{array}{l}19.1 \pm 12.1 \\
20(5-60)\end{array}$ & $\begin{array}{l}18.9 \pm 12.2 \\
20(5-60)\end{array}$ & $\begin{array}{l}22.8 \pm 14.2 \\
20(5-60)\end{array}$ \\
\hline $\begin{array}{l}\text { FEV1 \% pr. } \\
\text { mean } \pm \text { SD }\end{array}$ & $51.7 \pm 13.6$ & $51.7 \pm 13.6$ & $51 \pm 13.7$ & $97 \pm 14.7$ & $97 \pm 14.7$ & $95.2 \pm 13$ \\
\hline $\begin{array}{l}\text { FEV1/FVC } \% \\
\text { mean } \pm \text { SD }\end{array}$ & $61.3 \pm 8.5$ & $61.3 \pm 8.5$ & $62 \pm 8.1$ & $80 \pm 8.7$ & $80 \pm 8.7$ & $80.6 \pm 8.3$ \\
\hline $\begin{array}{l}\text { COPD stage } \\
\text { (GOLD 2009) } \\
\text { GOLD II } \\
\text { GOLD III } \\
\text { GOLD IV }\end{array}$ & $\begin{array}{l}(\mathrm{n}=189) \\
106(56.1 \%) \\
72(38.1 \%) \\
11(5.8 \%)\end{array}$ & $\begin{array}{l}(\mathrm{n}=191) \\
107(56 \%) \\
73(38.2 \%) \\
11(5.8 \%)\end{array}$ & $\begin{array}{l}(\mathrm{n}=91) \\
52(57.1 \%) \\
32(35.2 \%) \\
7(7.7 \%)\end{array}$ & & & \\
\hline
\end{tabular}




\section{Table 2 (on next page)}

Genotype and allele distributions according to TERC C>G (rs12696304) SNP in COPD patients and controls. 
1

\begin{tabular}{|c|c|c|c|c|c|c|}
\hline \multirow{2}{*}{$\begin{array}{c}\text { rs12696304 } \\
(\mathrm{C}>\mathrm{G})\end{array}$} & \multicolumn{2}{|c|}{ COPD patients } & \multicolumn{2}{|c|}{ Controls } & \multirow{2}{*}{$\begin{array}{l}\text { OR }(95 \% \mathrm{CI}), \mathrm{p}- \\
\text { value }\end{array}$} & \multirow{2}{*}{$\begin{array}{c}\text { OR }(95 \% \mathrm{CI}), \mathrm{p}- \\
\text { value } \\
\text { adjusted for sex and } \\
\text { age } \geq 60 \text { years })\end{array}$} \\
\hline & $\mathrm{n}$ & frequency & $\mathrm{n}$ & frequency & & \\
\hline & $n=189$ & & $\mathrm{n}=277$ & & & \\
\hline \multicolumn{7}{|c|}{ Genotype frequency } \\
\hline$C C$ & 97 & 0.513 & 109 & 0.393 & 1.0 (referent) & \\
\hline$C G$ & 78 & 0.413 & 139 & 0.502 & $\begin{array}{c}0.631(0.427- \\
0.931), \mathbf{p}=\mathbf{0 . 0 2 0}\end{array}$ & $\begin{array}{c}0.621(0.407- \\
0.949), \mathbf{p}=\mathbf{0 . 0 2 8}\end{array}$ \\
\hline$G G$ & 14 & 0.074 & 29 & 0.105 & $\begin{array}{c}0.542(0.271- \\
1.086), \mathrm{p}=0.084\end{array}$ & $\begin{array}{c}0.652(0.294-1.328) \\
p=0.222\end{array}$ \\
\hline$C G+G G$ & 92 & 0.487 & 136 & 0.557 & $\begin{array}{c}0.615(0.424- \\
0.894), \mathbf{p}=\mathbf{0 . 0 1 1}\end{array}$ & $\begin{array}{c}0.622(0.414- \\
0.933), \mathbf{p}=\mathbf{0 . 0 2 2}\end{array}$ \\
\hline \multicolumn{7}{|c|}{ Allele frequency } \\
\hline rs12696304C & 272 & 0.720 & 357 & 0.664 & 1.0 (referent) & \\
\hline rs12696304G & 106 & 0.280 & 197 & 0.356 & $\begin{array}{c}0.706(0.532- \\
0.938), \mathbf{p}=\mathbf{0 . 0 1 9}\end{array}$ & \\
\hline
\end{tabular}

2

3

4 


\section{Table 3 (on next page)}

Genotype and allele distributions according to TERC C > T (rs10936599) SNP in COPD patients and controls. 
1

\begin{tabular}{|c|c|c|c|c|c|c|}
\hline \multirow{2}{*}{$\begin{array}{c}\text { rs10936599 } \\
(\mathrm{C}>\mathrm{T})\end{array}$} & \multicolumn{2}{|c|}{ COPD patients } & \multicolumn{2}{|c|}{ Controls } & \multirow{2}{*}{$\begin{array}{l}\text { OR }(95 \% \mathrm{CI}), \mathrm{p}- \\
\text { value }\end{array}$} & \multirow{2}{*}{$\begin{array}{c}\text { OR (95\% CI }), p- \\
\text { value } \\
\text { adjusted for sex and } \\
\text { age } \geq 60 \text { years })\end{array}$} \\
\hline & $\mathrm{n}$ & frequency & $\mathrm{n}$ & frequency & & \\
\hline & $n=191$ & & $n=263$ & & & \\
\hline \multicolumn{7}{|c|}{ Genotype frequency } \\
\hline$C C$ & 119 & 0.623 & 138 & 0.525 & 1.0 (referent) & 1.0 (referent) \\
\hline$C T$ & 66 & 0.346 & 114 & 0.433 & $\begin{array}{c}0.671(0.455- \\
0.992), \mathbf{p}=\mathbf{0 . 0 4 5}\end{array}$ & $\begin{array}{c}0.683(0.447- \\
1.042), \mathrm{p}=0.077\end{array}$ \\
\hline$T T$ & 6 & 0.031 & 11 & 0.042 & $\begin{array}{c}0.633(0.227- \\
1.762), \mathrm{p}=0.381\end{array}$ & $\begin{array}{c}0.587(0.197-1.751) \\
p=0.339\end{array}$ \\
\hline$C T+T T$ & 72 & 0.377 & 125 & 0.475 & $\begin{array}{c}0.668(0.457- \\
0.976), \mathbf{p}=\mathbf{0 . 0 4 4}\end{array}$ & $\begin{array}{c}0.674(0.446- \\
1.016), \mathrm{p}=0.060\end{array}$ \\
\hline \multicolumn{7}{|c|}{ Allele frequency } \\
\hline rs10936599C & 304 & 0.796 & 390 & 0.741 & 1.0 (referent) & \\
\hline rs10936599T & 78 & 0.204 & 136 & 0.259 & $\begin{array}{l}0.736 \quad(0.537- \\
1.009), \mathrm{p}=0.058\end{array}$ & \\
\hline
\end{tabular}

2 


\section{Table 4 (on next page)}

Genotype combinations according to the two studied SNPs rs12696304 (C>G) and rs10936599 (C>T) and the frequency in controls and COPD patients. 
1

\begin{tabular}{|c|c|c|c|c|c|c|}
\hline \multirow{2}{*}{$\begin{array}{c}\text { rs12696304 } \\
(\mathrm{C}>\mathrm{G}) \text { and } \\
\mathrm{rs} 10936599 \\
(\mathrm{C}>\mathrm{T})\end{array}$} & \multicolumn{2}{|c|}{ COPD patients } & \multicolumn{2}{|c|}{ Controls } & \multirow{2}{*}{$\begin{array}{c}\text { OR }(95 \% \mathrm{CI}), \mathrm{p}- \\
\text { value }\end{array}$} & \multirow{2}{*}{$\begin{array}{c}\text { OR }(95 \% \mathrm{CI}), \mathrm{p}- \\
\text { value } \\
\text { adjusted for sex and } \\
\text { age } \geq 60 \text { years })\end{array}$} \\
\hline & $\mathrm{n}$ & frequency & $\mathrm{n}$ & frequency & & \\
\hline & $\mathrm{n}=190$ & & $\mathrm{n}=278$ & & & \\
\hline \multicolumn{7}{|c|}{ Genotype combination frequency } \\
\hline$C C / C C$ & 97 & 0.511 & 96 & 0.345 & 1.0 (referent) & 1.0 (referent) \\
\hline $\begin{array}{c}\text { All other } \\
\text { genotype } \\
\text { combinations }\end{array}$ & 93 & 0.489 & 182 & 0.655 & $\begin{array}{c}0.506(0.347- \\
0.737), \mathbf{p}<\mathbf{0 . 0 0 0 1}\end{array}$ & $\begin{array}{c}0.507(0.337- \\
0.764), \mathbf{p}=\mathbf{0 . 0 0 1}\end{array}$ \\
\hline
\end{tabular}

2

3 


\section{Table 5 (on next page)}

Leukocyte telomere length (LTL) in COPD patients and controls.

* LSD post hoc analysis of ANOVA test 
1

\begin{tabular}{|c|c|c|c|c|c|c|c|c|}
\hline & \multicolumn{4}{|c|}{ COPD patients } & \multicolumn{4}{|c|}{ Controls } \\
\hline & $\mathrm{n}$ & $\begin{array}{c}\text { LTL } \\
\text { mean } \\
(\mathrm{bp}) \\
\end{array}$ & $\begin{array}{l}\text { LTL } \\
\text { SEM } \\
(\mathrm{bp}) \\
\end{array}$ & $\mathrm{p}$-value & $\mathrm{n}$ & $\begin{array}{c}\text { LTL } \\
\text { mean } \\
(\mathrm{bp}) \\
\end{array}$ & $\begin{array}{l}\text { LTL } \\
\text { SEM } \\
(\mathrm{bp})\end{array}$ & p-value \\
\hline $\begin{array}{l}\text { rs12696304 } \\
(\mathrm{C}>\mathrm{G})\end{array}$ & 88 & & & 0.847 & 84 & & & 0.459 \\
\hline$C C$ & 54 & 17626 & 1543.44 & referent & 47 & 23749 & 3176.03 & referent \\
\hline$C G$ & 30 & 18217 & 1024.81 & $0.818^{*}$ & 28 & 18540 & 1885.04 & $0.226^{*}$ \\
\hline$G G$ & 4 & 15164 & 5083.14 & $0.673 *$ & 9 & 19964 & 4445.9 & $0.562 *$ \\
\hline $\begin{array}{l}\text { rs10936599 } \\
(\mathrm{C}>\mathrm{T})\end{array}$ & 90 & & & & 86 & & & 0.925 \\
\hline$C C$ & 64 & 17809 & 1435.59 & referent & 49 & 21787 & 3016.24 & referent \\
\hline$C T$ & 24 & 18413 & 2464.21 & $0.828^{*}$ & 31 & 20199 & 2204.13 & $0.703 *$ \\
\hline$T T$ & 2 & 11011 & 1935.76 & $0.416^{*}$ & 6 & 20359 & 6633.99 & $0.859 *$ \\
\hline $\begin{array}{l}\text { rs12696304 } \\
(\mathrm{C}>\mathrm{G}) \text { and } \\
\text { rs10936599 } \\
(\mathrm{C}>\mathrm{T})\end{array}$ & 88 & & & & 84 & & & \\
\hline$C C / C C$ & 34 & 17926 & 1543.44 & referent & 42 & 22988 & 3438.71 & referent \\
\hline $\begin{array}{l}\text { All other } \\
\text { genotype } \\
\text { combinations }\end{array}$ & 88 & 17858 & 1866.73 & 0.925 & 42 & 20226 & 1850.85 & 0.482 \\
\hline
\end{tabular}




\section{Figure 1}

Leukocyte telomere length (LTL) in COPD patients and controls. The LTL is presented as mean \pm standard deviation (SEM).

The LTL is presented as mean \pm standard deviation (SEM).

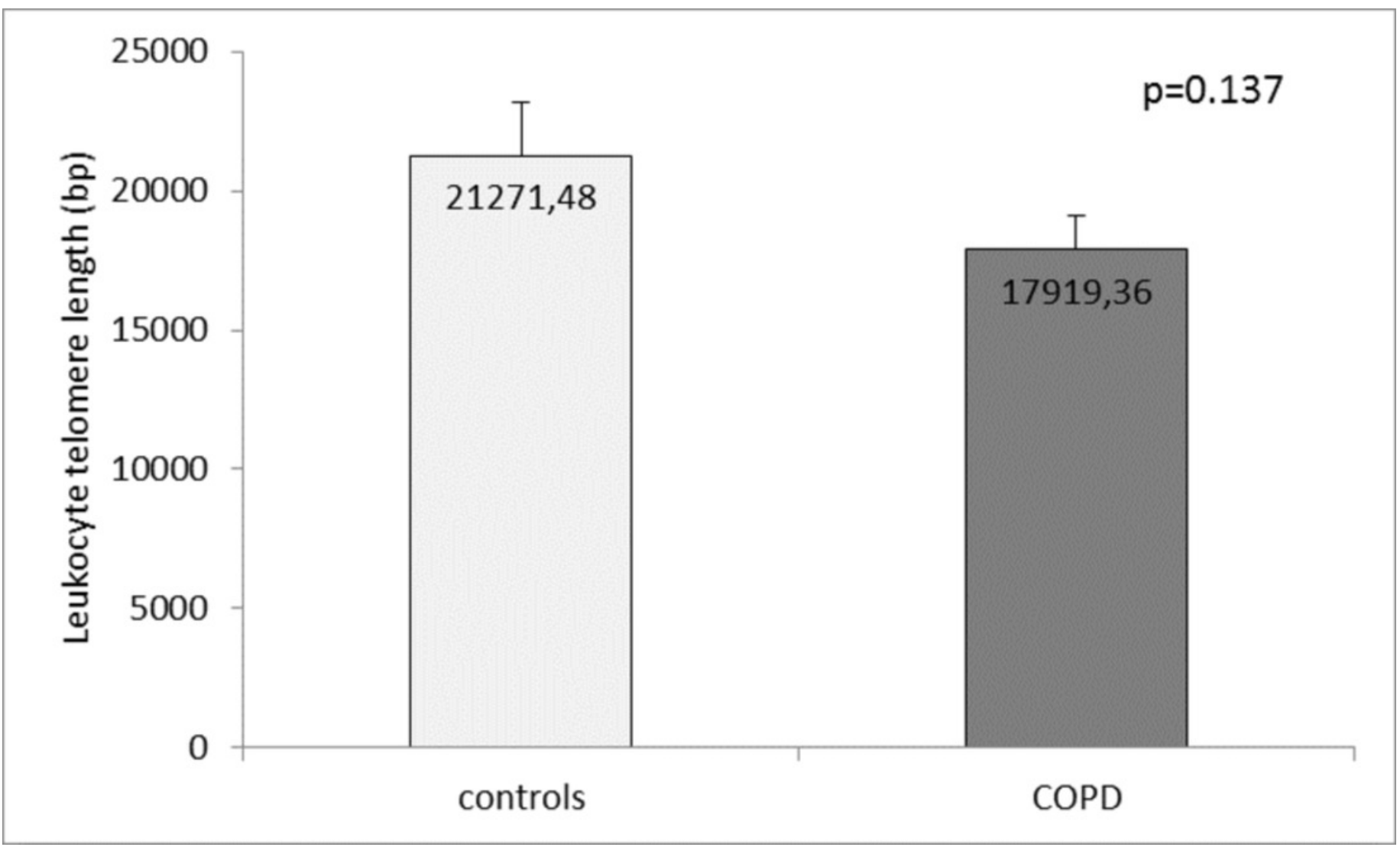


Figure 2

Leukocyte telomere length (LTL) in COPD patients and controls less than and above 60 years of age.

The LTL is presented as mean \pm standard error of mean (SEM).

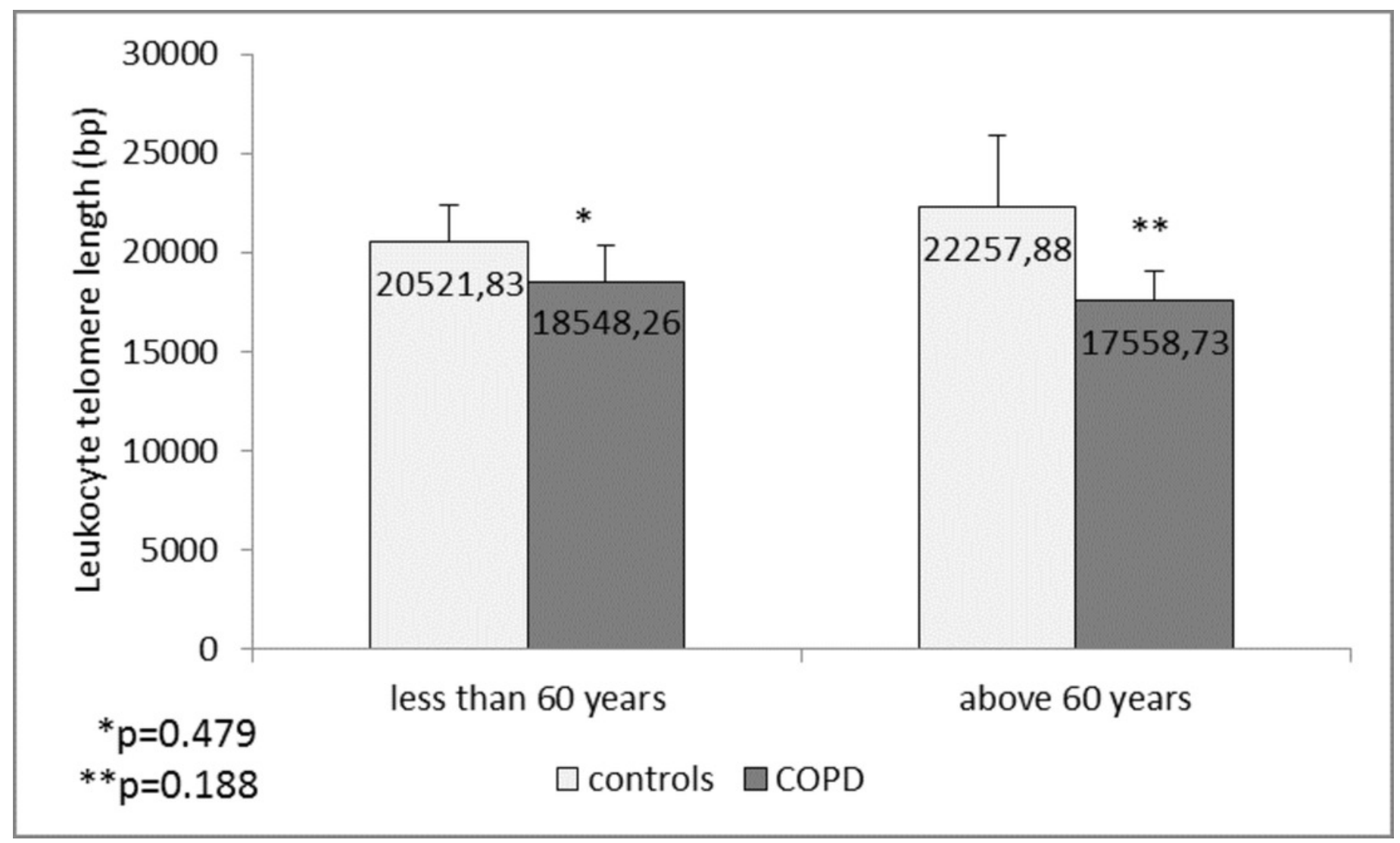

